\title{
EFFECT OF SNAKE VENOM DERIVED FIBRIN GLUE ON THE TENDON HEALING IN DOGS. CLINICAL AND BIOMECHANICAL STUDY
}

FERRARO G. C. (1), MORAES J. R. E. (1), SHIMANO A. C. (2), PEREIRA G. T. (3), MORAES F. R. (1), BUENO DE CAMARGO M. H. (1)

(1) Department of Veterinary Pathology (DPVE) School of Agrarian and Veterinary Sciences (FCAV), São Paulo State University (UNESP), Jaboticabal, São Paulo, Brazil; (2) Laboratory of Bioengineering, Ribeirão Preto School of Medicine (FMRP), São Paulo University (USP), Ribeirão Preto, São Paulo, Brazil; (3) Department of Exact Sciences, School of Agrarian and Veterinary Sciences (FCAV), São Paulo State University (UNESP), Jaboticabal, São Paulo, Brazil.

ABSTRACT: The aim of this study was to evaluate the effect of snake venom derived fibrin glue on the strength of tendon healing in dogs. The deep digital flexor tendon of the $5^{\text {th }}$ digit of 24 thoracic limbs was partially sectioned for adhesive application. On the $7^{\text {th }}, 15^{\text {th }}$, and $30^{\text {th }}$ postoperative day tendons segments were removed for the clinical and biomechanical study. Results indicated that $62.5 \%$ of the tendons showed stump retraction and $20.8 \%$ moderate to excessive adherence, which affected gliding. The biomechanical evaluation showed that, over time, tendon healing gained progressive resistance for maximum traction and permanent deformations with satisfactory results on the $15^{\text {th }}$ day for rigidity and resilience compared to the other two studied periods. Snake venom derived fibrin glue promotes healing in dog flexor tendon.

KEY WORDS: dog, fibrin glue, mechanical properties, snake venom, healing, tendon.

\section{CORRESPONDENCE TO:}

J. R. E. MORAES, Laboratório de Patologia Experimental e Comparada, Departamento de Patologia Veterinária, FCAV/UNESP, Via de Acesso Professor Paulo Donato Castellani, Km 5, 14884-900, Jaboticabal, SP, Brasil, Phone: 55016 3209 2662, Email: jrmoraes@fcav.unesp.br 


\section{INTRODUCTION}

Tendons must glide to efficiently translate muscular forces into angular motion at joints. Successful repair of lacerated tendons must restore their continuity without leading to restrictive adhesions or geometric impediments to gliding (9).

Attempts to prevent adhesions and improve tendon healing have been made with variable success. These include the morphological and biomechanical trials with different suture materials and repair techniques (16), different postoperative managements (19), grafts (21), and different substances as corticosteroids (12), dextran 70 (8), collagen inhibitor (24), ibuprofen (31), sodium hyaluronate (34), aprotinin (13), 5-fluorouracil (17), TGB- $\beta$ (35), and fibrin adhesive (11).

Previous studies have suggested a useful role for the application of fibrin adhesive to tendon ruptures $(18,22,26,29)$. They showed that it helped achieve a better anatomic reconstruction and reduce the amount of stabilizing fixation sutures needed (7); it also improved tensile strength of the repair and made plaster cast immobilization unnecessary in most cases (32).

The objective of this study was to evaluate the clinical evolution of tendon gliding and the strength of the deep digital flexor tendon (DDFT) healing of dog thoracic limbs during three periods, using snake venom derived fibrin glue associated with bubaline fibrinogen as a substitute for conventional tenorrhaphy.

\section{MATERIALS AND METHODS}

Twenty-four left or right thoracic limbs from 12 healthy, adult mongrels $(10-15 \mathrm{~kg})$ were used. Dogs underwent a preliminary adjustment period (15 days minimum) when they received a balanced diet and water ad libitum. They were individually housed throughout the experiment.

The thoracic limbs were randomly divided into 3 experimental groups of 10. Each group corresponded to the day of evaluation after the glue application: $7^{\text {th }}, 15^{\text {th }}$, and $30^{\text {th }}$ day of the postoperative period.

After a 6-hour fast and a 3-hour water deprivation, animals received Levomepromazine hydrochloride (1 $\mathrm{mg} / \mathrm{kg}$, intravenously) as pre-anesthetic, and Tiletamine and Zolazepam (10 mg/kg, subcutaneously) as dissociative anesthesia. Later, they received Buprenorphine hydrochloride $(0.01 \mathrm{mg} / \mathrm{kg}$, subcutaneously) and Penicillin $\mathrm{G}$ benzathine $(40,000 \mathrm{UI} / \mathrm{kg}$, subcutaneously). 
G. C. Ferraro et al. EFFECT OF SNAKE VENOM DERIVED FIBRIN GLUE ON THE TENDON HEALING IN DOGS. CLINICAL AND BIOMECHANICAL STUDY. J. Venom. Anim. Toxins incl. Trop. Dis., 2005, 11, 3, p. 263

The dorsal lateral region of the paw was shaved and prepared with povidone iodine solution. The skin and the subcutaneous tissue of the lateral region of the $2^{\text {nd }}$ digit were incised, followed by divulsion of the adjacent tissues. After that, we carried out the incision of the synovial sheath, location of the DDFT, partial transverse tenotomy (approximately $2 / 3$ of the diameter) between the $2^{\text {nd }}$ and $3^{\text {rd }}$ annular ligament, drying of the tendon stumps, application of two drops of fibrin glue, coaptation of tendon stumps for two minutes, and skin suture.

After cleaning the surgical wound, a protective bandage was applied, using orthopedic cotton. The limb was immobilized using a PVC splint placed at $90^{\circ}$ on the carpal joint for protection during movement. We also used an "Elizabethan" type collar to restrict dog head movement. Animals underwent daily physical therapy, with controlled passive flexion and extension of the operated on digit for five minutes up until collection. The splint was removed before the physical therapy and then put back after that.

On collection day the animals were subjected again to the anesthetic and surgical procedures described. Tendon segments of $2 \mathrm{~cm}$, with centralized section, were removed. Macroscopic alterations of tissue repair were evaluated at this moment, considering stump coaptation, adhesion formation, and tendon gliding.

The $5^{\text {th }}$ digit tendon segments were identified, immersed in $0.9 \%$ saline, and frozen until the mechanical traction assay; this was performed in a Universal Test Machine (UTM). The biomechanical properties evaluated were:

Elasticity limit - it is the maximum load that the material under study can take before going back to its initial conditions. The loads and deformations can be determined as the last point of the straight segment of the curve;

Maximum limit - it is the maximum load that the material can take before the rupture. It can be determined by the maximum deformation and load recorded in each assay; Rigidity - it is equal to the module of the elasticity, which relates the load and deformation in the elastic phase of the material. It can be determined by the tangent of the inclination of the straight line in the linear phase of the material;

Resilience - it is the capacity of the material to absorb deformation energy in the elastic phase. It can be determined by the area of the rectangle triangle formed below the straight line in the elastic phase of the material.

Both ends of the tendon segments were fastened at a standard $10 \mathrm{~mm}$ distance apart. A pre-load of $0.1 \mathrm{Kgf}$ was applied, with accommodation time of 30 seconds. A 
G. C. Ferraro et al. EFFECT OF SNAKE VENOM DERIVED FIBRIN GLUE ON THE TENDON HEALING IN DOGS. CLINICAL AND BIOMECHANICAL STUDY. J. Venom. Anim. Toxins incl. Trop. Dis., 2005, 11, 3, p. 264

load cell $\left(\mathrm{Kratos}^{\circledR}\right)$ with capacity of $50 \mathrm{Kgf}$, associated to an extensometry bridge (Sodomex ${ }^{\circledR}$ ), for the loads reading, was coupled to the UTM at a constant speed of $0.8 \mathrm{~mm} / \mathrm{min}$. A dial micrometer (Mitutoyo ${ }^{\circledR}, 0.01 \mathrm{~mm}$ precision) was used to measure the deformations, and the reading was recorded at $0.05 \mathrm{~mm}$ intervals, until the abrupt fall of the applied load (Figure 1).

Evaluation of the three treatments on the four biomechanical properties was performed by an entirely randomized design, with eight repetitions. In analysis of variance, means were compared by the $F$ test at $1 \%$ probability. Mean differences were tested with the Tukey test at $5 \%$ probability level (23). Values were expressed as mean \pm standard error.

Fibrin glue is composed of the thrombin-like fraction from Crotalus durissus terrificus venom, cryoprecipitate from bubaline blood, and calcium chloride, obtained as per Thomazini-Santos (30). It was applied using a " $Y$ " shaped syringe mixing the fractions $(300 \mu \mathrm{l}$ cryoprecipitate [syringe 1]; $250 \mu \mathrm{l}$ calcium chloride and $50 \mu \mathrm{l}$ thrombin-like fraction [syringe 2]), at surgery.

\section{RESULTS}

From the 24 tendons evaluated, $62.5 \%$ (15) showed slight to moderate stump retraction (approximately $2 \mathrm{~mm}$ ); the 30-day group showing the best coaptation. Adhesion to the synovial sheath and adjacent tissues was slight in $37.5 \%$ (9), and moderate to excessive in $20.8 \%$ (5), compromising tendon gliding.

Deformation $\mathrm{x}$ load graphs of the mechanical assays performed for each period are shown in Figure 2. There was not rupture of the tendon segments. Analysis of variance showed a significant difference $(p<0.01)$ for the four properties evaluated between the three treatment periods.

The highest deformation mean of the elasticity limit occurred on the $30^{\text {th }}$ day $(1.48 \pm$ $\left.0.09 \times 10^{-3} \mathrm{~m}\right)$, followed by the $15^{\text {th }}\left(0.96 \pm 0.03 \times 10^{-3} \mathrm{~m}\right)$ and $7^{\text {th }}$ days $(0.92 \pm 0.07$ $\left.\mathrm{x} 10^{-3} \mathrm{~m}\right)$. The highest mean for load was also on the $30^{\text {th }}$ day $(39.83 \pm 1.68 \mathrm{~N})$, followed by the $15^{\text {th }}(23.97 \pm 0.65 \mathrm{~N})$ and $7^{\text {th }}$ days $(16.03 \pm 1.12 \mathrm{~N})$. The Tukey test showed a significant difference for deformation means only on the $30^{\text {th }}$ day $(p<0.05)$. There was a significant difference for mean loads $(p<0.05)$ between all the three treatment periods (Figure 3A). 
The highest deformation mean of the maximum limit was on the $30^{\text {th }}$ day $(2.63 \pm 0.09$ $\left.\times 10^{-3} \mathrm{~m}\right)$, followed by the $7^{\text {th }}\left(1.61 \pm 0.08 \times 10^{-3} \mathrm{~m}\right)$ and $15^{\text {th }}$ days $\left(0.16 \pm 0.07 \times 10^{-3} \mathrm{~m}\right)$. The highest load mean was on the $30^{\text {th }}$ day $(55.94 \pm 1.96 \mathrm{~N})$, followed by the $15^{\text {th }}$ $(31.88 \pm 0.95 \mathrm{~N})$ and $7^{\text {th }}$ days $(21.45 \pm 1.09 \mathrm{~N})$. The Tukey test showed that mean deformations were coincident only on the $7^{\text {th }}$ and $15^{\text {th }}$ days $(p>0.05)$. A significant difference $(p<0.05)$ was seen for mean loads between the three treatment periods (Figure 3B).

The highest rigidity mean was on the $30^{\text {th }}$ day $(31362.87 \pm 1511.83 \mathrm{~N} / \mathrm{m})$, followed by the $15^{\text {th }}(28076.04 \pm 1121.63 \mathrm{~N} / \mathrm{m})$ and $7^{\text {th }}$ days $(18396.12 \pm 687.43 \mathrm{~N} / \mathrm{m})$. The Tukey test showed significant difference for means only on the $7^{\text {th }}$ day $(p<0.05)$ (Figure $3 C$ ). The highest resilience mean was also on the $30^{\text {th }}$ day $\left(12.43 \pm 1.35 \times 10^{-3} \mathrm{~J}\right)$, followed by the $15^{\text {th }}\left(5.18 \pm 0.44 \times 10^{-3} \mathrm{~J}\right)$ and $7^{\text {th }}\left(3.69 \pm 0.54 \times 10^{-3} \mathrm{~J}\right)$ days. The Tukey test showed that means were coincident only on the $7^{\text {th }}$ and $15^{\text {th }}$ days $(p>0.05)$ (Figure $3 \mathrm{D})$.

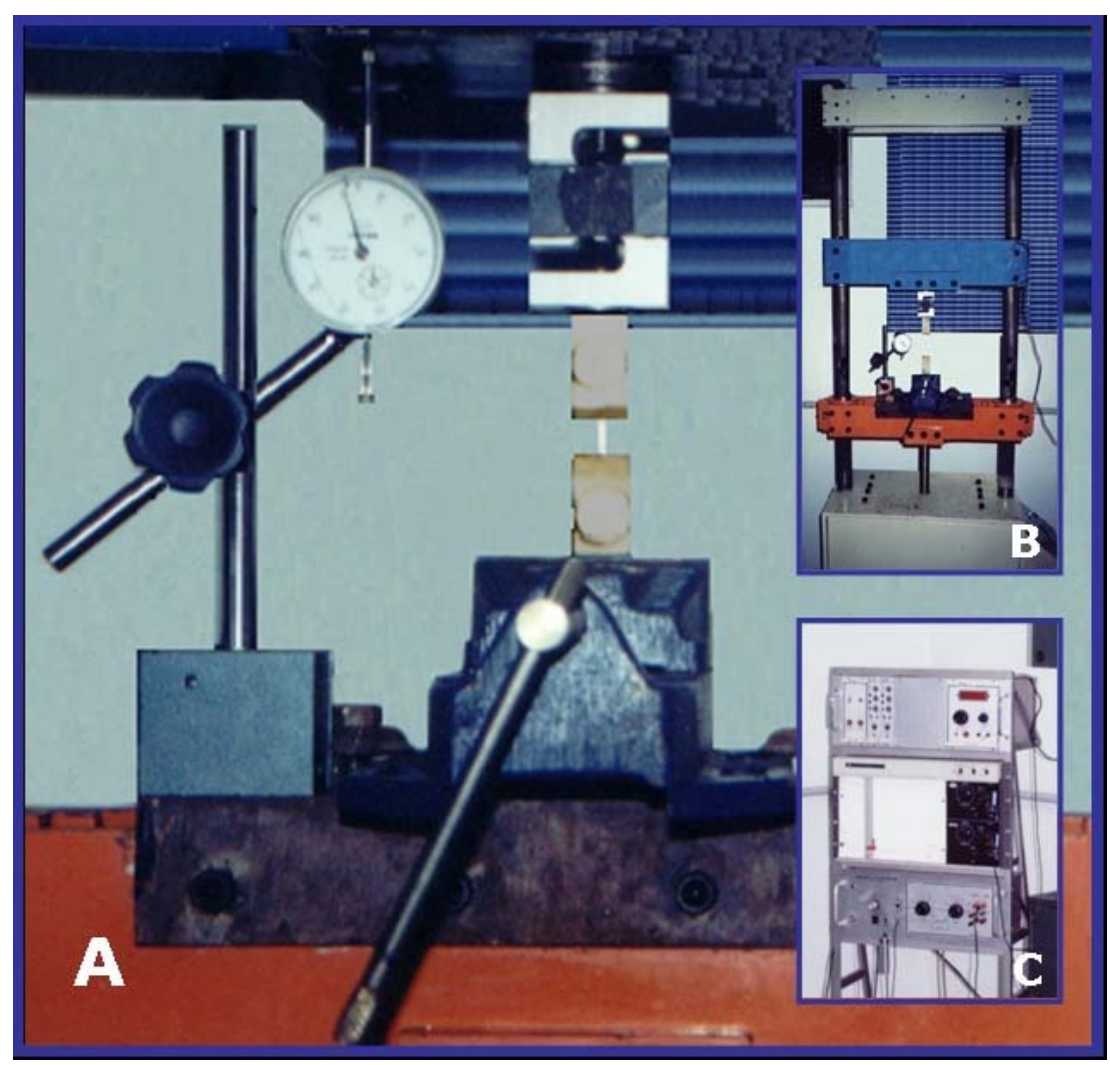

Figure 1: Dog tendon segment during the mechanical traction assay. Details of the jaws and the dial micrometer (A); Universal Test Machine overall view (B); extensometry bridge $(C)$. 


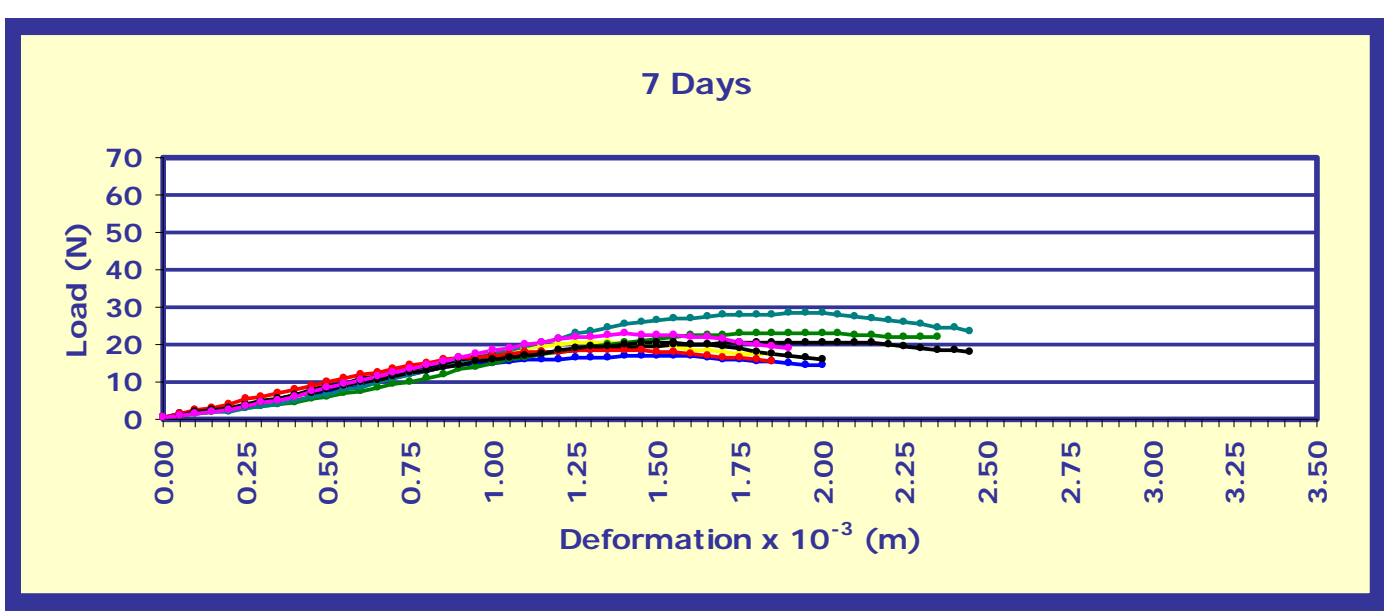

Figure 2A

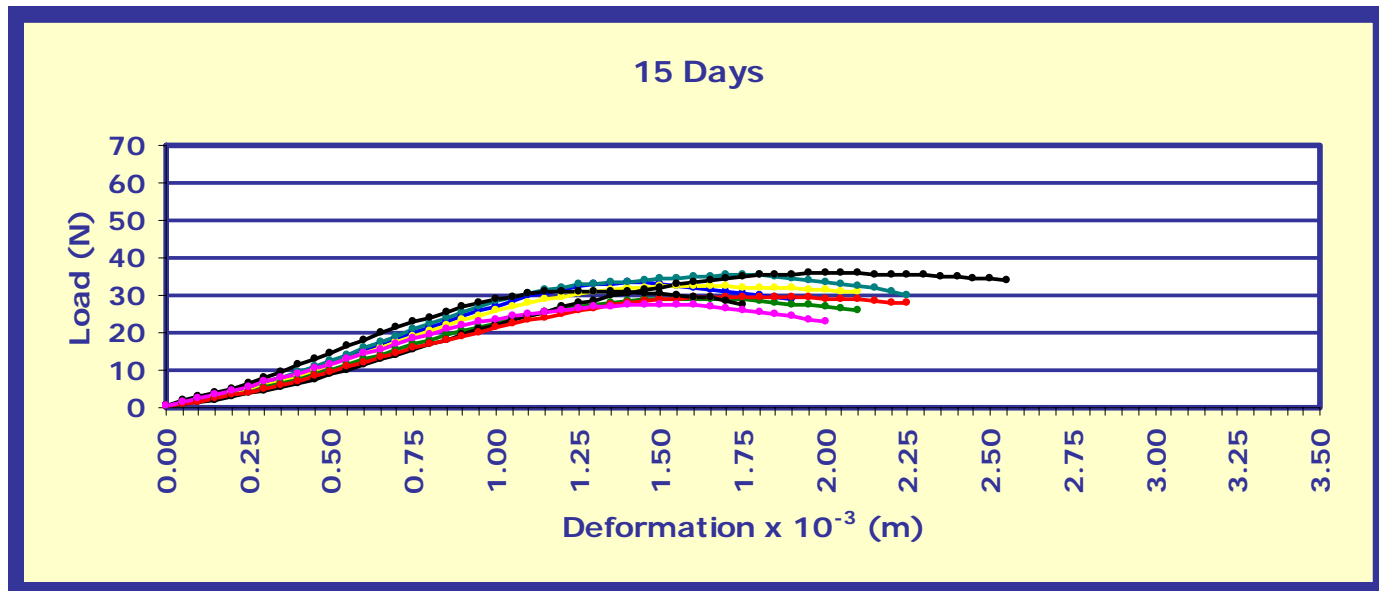

Figure 2B

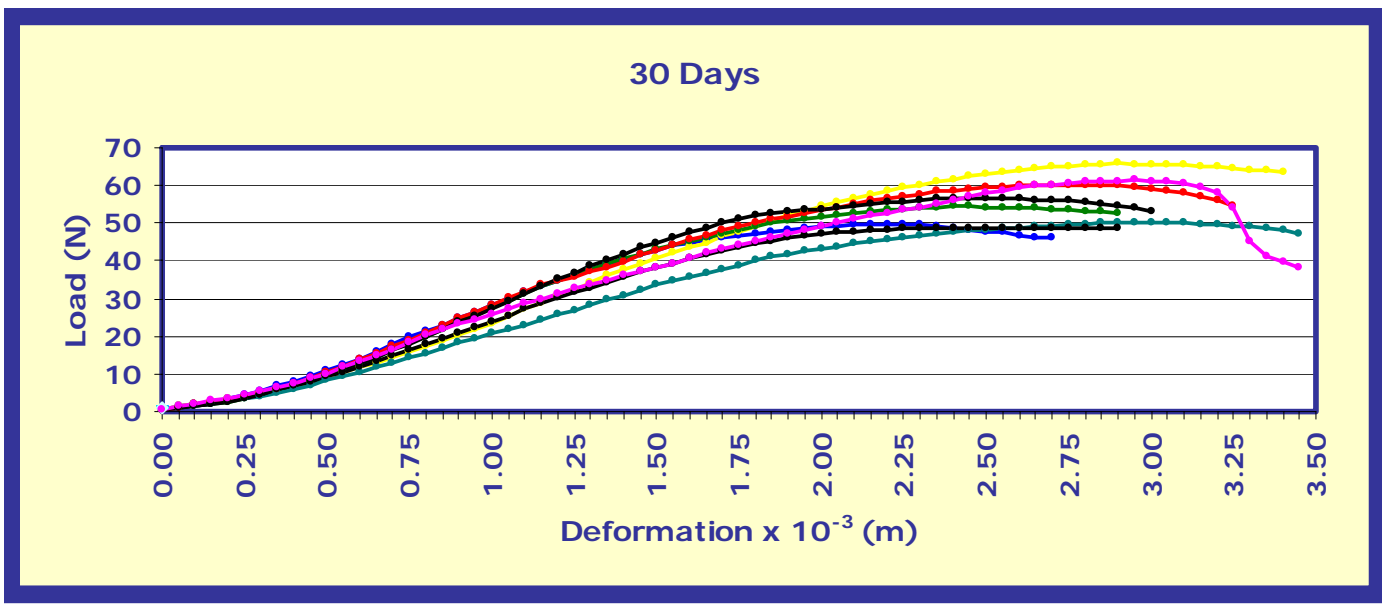

Figure 2C

Figure 2: Load $x$ deformation curves of traction tests of the deep digital flexor tendon segments of dog thoracic limb using snake venom derived glue on the $7^{\text {th }}(A), 15^{\text {th }}$ $(B)$ and $30^{\text {th }}(C)$ day of observation. 
G. C. Ferraro et al. EFFECT OF SNAKE VENOM DERIVED FIBRIN GLUE ON THE TENDON HEALING IN DOGS. CLINICAL AND BIOMECHANICAL STUDY. J. Venom. Anim. Toxins incl. Trop. Dis., 2005, 11, 3, p. 267

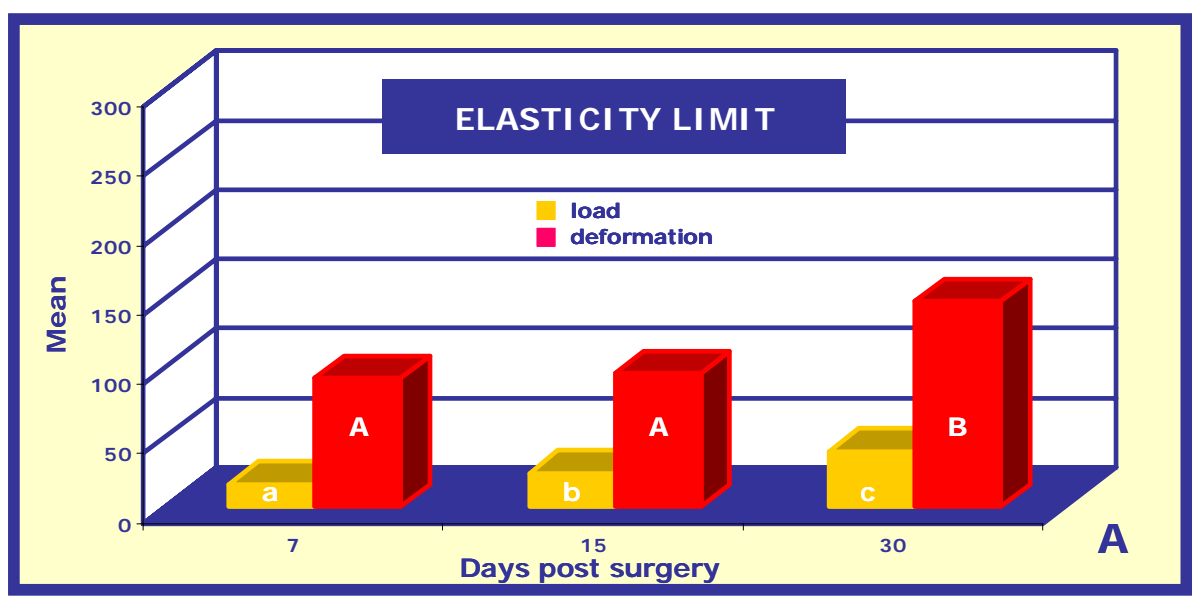

Figure $3 \mathrm{~A}$

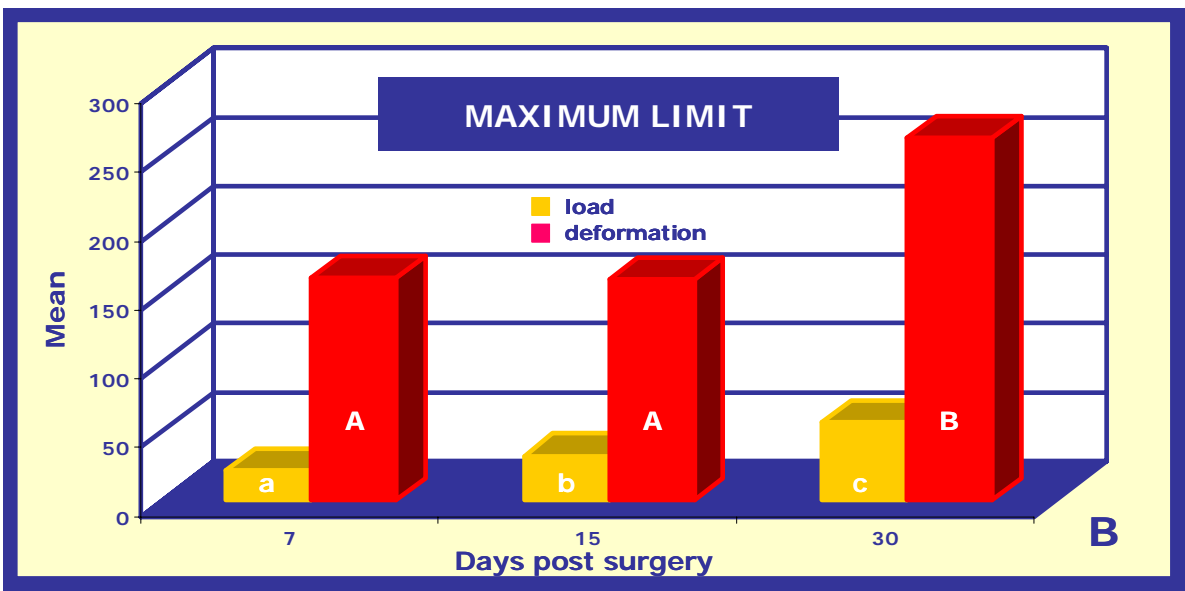

Figure 3B

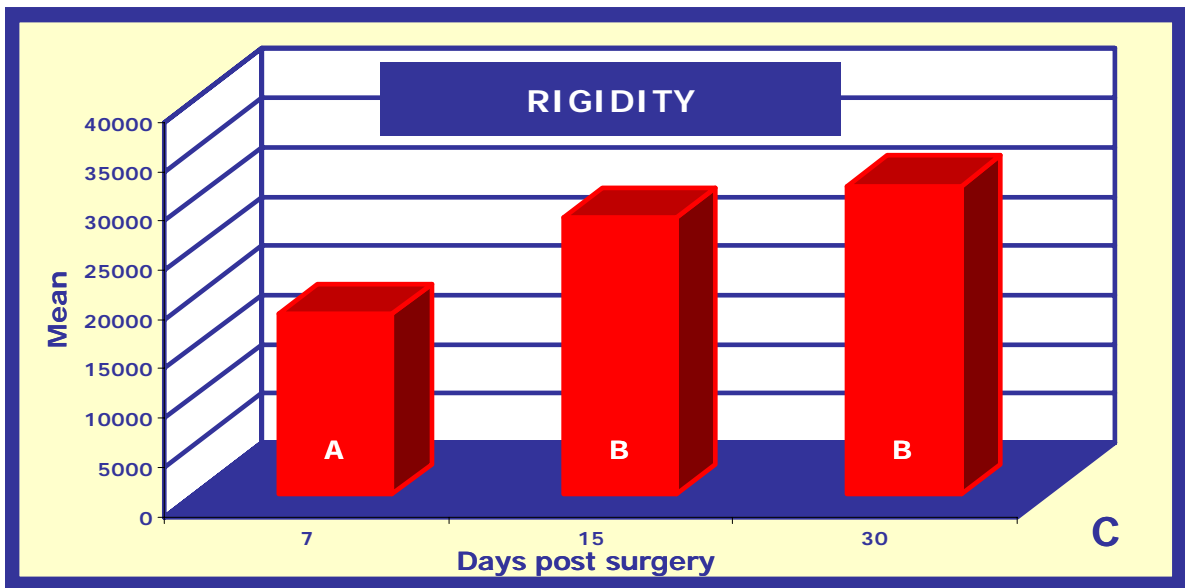

Figure $3 \mathrm{C}$ 


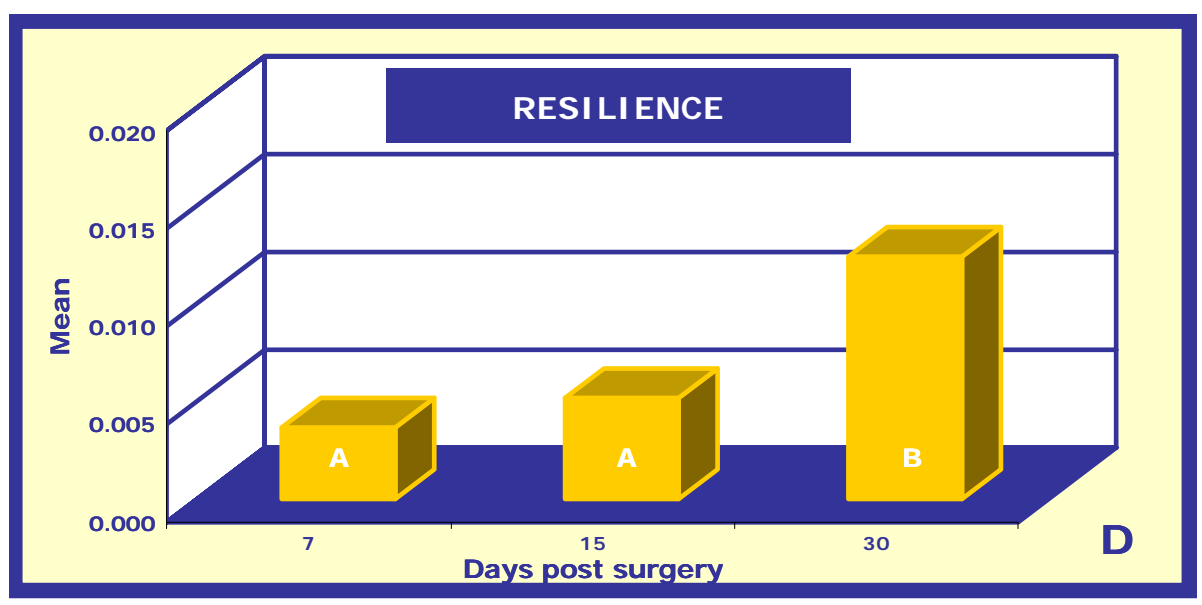

Figure 3D

Figure 3: Mean variation of the four biomechanical properties evaluated in the traction tests of the deep digital flexor tendon segments in dog thoracic limb using snake venom derived fibrin glue at each observation period. Load $[N]$ and deformation $\times 10^{-5}[\mathrm{~m}]$ in the elasticity limit $(\mathrm{A})$; load $[\mathrm{N}]$ and deformation $\times 10^{-5}[\mathrm{~m}]$ in the maximum limit $(B)$; rigidity $[N / m](C)$; and resilience [J] (D). Means with equal capital or small letters on the bars are not different by the Tukey test ( $p>0.05)$.

\section{DISCUSSION}

The ideal tendon repair technique should restore the continuity of the tendon and allow normal gliding. Repair strength should be adequate to allow early postoperative motion regimens to maximize tendon strength and mobility. The optimal repair technique must be able to withstand the rigors of early motion and also must not interfere with tendon healing. Repair strength as well as resistance to gap formation are paramount (9). In the last decades the clinicians have become increasingly aware of the biological evidence of accelerated tendon healing, and this awareness has had a powerful influence on the strategies adopted for the treatment of tendon injuries (19).

It is well known that the tendon healing with adhesion formation is unfavorable: while acting as conduits for cells and blood vessels, the adhesions limit tendon gliding and function (9).

Our results showed that $20.8 \%$ of tendons had moderate to excessive adhesion. This may be attributable to excessive tendon manipulation during surgery and/or the fibrin 
G. C. Ferraro et al. EFFECT OF SNAKE VENOM DERIVED FIBRIN GLUE ON THE TENDON HEALING IN DOGS. CLINICAL AND BIOMECHANICAL STUDY. J. Venom. Anim. Toxins incl. Trop. Dis., 2005, 11, 3, p. 269

glue, which, due to its low viscosity, infiltrated in tissues adjacent to the section site as a result of the technique used.

Adhesion formation is limited by early motion regimens that generate gliding of the repair site $(3,6)$. Despite a matter of controversy whether postoperative mobilization causes any fundamental changes in the successive phases of tendon healing or - as compared with postoperative immobilization - mobilization simply accelerates the restoration of biomechanical properties (19), in this study, the results showed that immobilization associated with adequate daily passive movement of the digit that was operated on also helped prevent excessive formation of adhesion to the neighboring tissues, favoring a lower formation of fibrous connective tissue and allowing better sliding in most operated on tendons, as reported in several other experimental species $(3,4,6,16)$.

Our results showed that partial section of tendon caused secondary retraction between tendon stumps in $62.5 \%$ of the studied tendons. This can be attributed to the high tension required in tendon extremities, once the glue did not provide enough resistance to traction in the ruptured area, and also to the surgical technique and the post surgery rehabilitation program. However, previous studies report that stump separation secondary to mobilization is not associated with decreased breaking strength (15), and also that secondary separation of stumps, less than or equal to 2 $\mathrm{mm}$, did not compromise flexor tendon healing in dogs subjected to tenorrhaphy and postoperative motion regimens (25)

In the immediate postoperative period, resistance of repair depends predominantly on the number of suture stitches (33). In the first $24 \mathrm{~h}$ after lesion, an appropriately coapted wound shows resistance due to formation of fibrin coagulate and then by the presence of new capillaries. Four to six days later, this increases significantly, reaching maximum resistance between the $14^{\text {th }}$ and $16^{\text {th }}$ day, when it is associated with fibroplasia and collagen production (10). Tendon resistance increases 15 times after ten days with a peak between the $14^{\text {th }}$ and $28^{\text {th }}$ day, reaching a level 22 times above the normal. Its decline is slow, with the level still 15 times above the normal at 84 days of evolution (2).

In this study, the evaluation of the four biomechanical properties allowed us to observe that tendon healing gained progressive resistance with time for maximum traction force and permanent deformations. On the $15^{\text {th }}$ day it showed satisfactory rigidity and resilience in relation to the other two studied periods. These results may 
G. C. Ferraro et al. EFFECT OF SNAKE VENOM DERIVED FIBRIN GLUE ON THE TENDON HEALING IN DOGS. CLINICAL AND BIOMECHANICAL STUDY. J. Venom. Anim. Toxins incl. Trop. Dis., 2005, 11, 3, p. 270

be considered a direct answer of the proliferative phase of tendon healing, in which fibroblast migration associated with angiogenesis and collagen syntheses at the scar site are pronounced.

Several studies have suggested benefits in the use of fibrin adhesives in traumatic $(7,18,22,32)$ and experimental $(11,26-29)$ ruptures of tendons in different species. They have reported that these adhesives act as a surface that favors fibroblast migration with mitogenic influence, which increases collagen secretion and its early stratification $(7,20)$ in addition to increased repair strength, decreased surgical time and post surgery mobilization in some cases $(27,28,32)$. However, not all of them report its beneficial effects on tendon healing $(1,5,14)$; but they admit possible flaws in the pre-established design or technique used $(7,14)$.

The clinical and biomechanical results of this study show satisfactory use of snake venom derived fibrin glue in the flexor tendon healing of dogs. We still highlight that the change of technique in applying glue using sterile insulation to keep the surgical site separate from neighboring tissues during adhesive components reaction can effectively reduce the level of adhesion, as described by other authors in rabbit tendons $(5,11)$.

Finally, the use of snake venom derived fibrin glue prevented excessive formation of adhesion, and also allowed a progressive increase in resistance for maximum traction strength and permanent deformations. Thus, snake venom derived fibrin glue can be used as a promoter for healing in dog flexor tendon.

\section{ACKNOWLEDGEMENTS}

The authors thank the State of São Paulo Research Foundation (FAPESP) for financing this study; Center for the Study of Venoms and Venomous Animals (CEVAP), São Paulo State University (UNESP), Botucatu, São Paulo, Brazil; Laboratory of Micology, Department of Clinical Analysis, School of Pharmaceutical Sciences (FCF), São Paulo State University (UNESP), Araraquara, São Paulo, Brazil; Laboratory of Division into Fractions, Blood Bank and Laboratory of Bioengineering, Ribeirão Preto School of Medicine (FMRP), São Paulo University (USP), Ribeirão Preto, SP, Brazil; Fort-Dodge ${ }^{\odot}$, Campinas, São Paulo, Brazil; FriRibe $^{\odot}$, Pitangueiras, São Paulo, Brazil. 


\section{REFERENCES}

1 BOSCH P., HERTZ H., LINTNER F., NOWOTNY R., ENGEL A. Experimentelle Sehnenklebung. In: COTTA H., BRAUN A. Fibrinkleber in orthopadie und traumatologie. Stuttgart: Thieme-Verlag, 1982: 187.

2 EARLEY TD. Tendon disorders. IN: BOJRAB MJ. Pathophysiology in small animal surgery. Philadelphia: Lea \& Febiger, 1981: 5851-66.

3 EDINBURG M., WIDGEROW AD., BIDDULPH SL. Early postoperative mobilization of flexor tendon injuries using a modification of the Kleinert technique. J. Hand Surg. Am., 1987, 12, 34-8.

4 FEEHAN LM., BEAUCHENE JG. Early tensile properties of healing chicken flexor tendons: early controlled passive motion versus postoperative immobilization. J. Hand Surg. Am., 1990, 15, 63-8.

5 FRYKMAN E., JACOBSSON S., WIDENFALK B. Fibrin sealant in prevention of flexor tendon adhesions: an experimental study in the rabbit. J. Hand Surg. Am., 1993, 18, 68-75.

6 GELBERMAN RH., WOO SL., LOTHRINGER K., AKESON WH., AMIEL D. Effects of early intermittent passive mobilization on healing canine flexor tendons. J. Hand Surg. Am., 1982, 7, 170-5.

7 GLUCKERT K., PESCH HJ., WESELOH G. Fibrinklebung bei sehnenlasionenexperimentelle erfahrungen und klinische aspekte. In: SCHEELE J. Fibrinklebung. Berlin: Springer-Verlag, 1984: 221.

8 GREEN S., SZABO R., LANGA, V., KLEIN M. The inhibition of flexor tendon adhesions. Bull. Hosp. Jt. Dis. Orthop. Inst., 1986, 46, 6-21.

9 GREENWALD DP., HONG HZ., MAY JUNIOR JW. Mechanical analysis of tendon suture techniques. J. Hand Surg. Am., 1994, 19, 641-7.

10 JOHNSTON DE. Tendons, skeletal muscles, and ligaments in health and disease. In: NEWTON CD., NUNAMAKER DM. Textbook of small animal orthopaedics. Philadelphia: Lippincott, 1985: 65-76.

11 JONES ME., BURNETT S., SOUTHGATE A., SIBBONS P., GROBBELAAR AO., GREEN CJ. The role of human-derived fibrin sealant in the reduction of postoperative flexor tendon adhesion formation in rabbits. J. Hand Surg. Br., 2002, 27, 278-82. 
G. C. Ferraro et al. EFFECT OF SNAKE VENOM DERIVED FIBRIN GLUE ON THE TENDON HEALING IN DOGS. CLINICAL AND BIOMECHANICAL STUDY. J. Venom. Anim. Toxins incl. Trop. Dis., 2005, 11, 3, p. 272

12 KAPETANOS $\mathrm{G}$. The effect of the local corticosteroids on the healing and biomechanical properties of the partially injured tendon. Clin. Orthop., 1982, $163,170-9$.

13 KOMURCU M., AKKUS O., BASBOZKURT M., GUR E., AKKAS N. Reduction of restrictive adhesions by local aprotinin application and primary sheath repair in surgically traumatized flexor tendons of the rabbit. J. Hand Surg. Am., 1997, 22, 826-32.

14 LUSARDI DA., CAIN JUNIOR JE. The effect of fibrin sealant on the strength of tendon repair of full thickness tendon lacerations in the rabbit Achilles tendon. J. Foot Ankle Surg., 1994, 33, 443-7.

15 MASON M., ALLEN HS. The rate of healing of tendons. Ann. Surg., 1941, 113, 424-59.

16 MORAES JRE. Estudo comparado dos aspectos morfofuncionais de tendões na constituição normal e na evolução do processo cicatricial. Jaboticabal: Universidade Estadual Paulista, Faculdade de Ciências Agrárias e Veterinárias, 2001. 172p. [Tese - Livre Docência]

17 MORAN SL., RYAN CK., ORLANDO GS., PRATT CE., MICHALKO KB. Effects of 5-fluorouracil on flexor tendon repair. J. Hand Surg. Am., 2000, 25, 242-51.

18 PAAR O., BERNETT P. Therapy of Achilles tendon rupture in athletes. Advantages of fibrin gluing. Fortschr. Med., 1984, 102,1106-8.

19 PALMES D., SPIEGEL HU., SCHNEIDER TO., LANGER M., STRATMANN U., BUDNY T., PROBST A. Achilles tendon realing: long-term biomechanical effects of postoperative mobilization and immobilization in a new mouse model. J. Orthop. Res., 2002, 20, 939-46.

20 PEACOCK EE., VAN WINKLE, W. Wound repair. 3ed. Philadelphia: WB Saunders, 1984: 263-78.

21 RAISER AG., GRAÇA DL., PIPPI NL., ZINN LL., SILVEIRA DS., BORDIN AI., BAIOTTO GC., RIOS MV., SILVEIRA AFD. Homoimplante ortotópico de tendão calcâneo em cães. Conservação, assepsia e implantação. Cienc. Rural, 2001, 31, 89-94.

22 RUPP G. Die fibringeklebte Achillessehnenruptur. In: COTTA H., BRAUN A. Fibrinkleber in orthopadie und traumatologie. Stuttgart: Thieme-Verlag, 1982: 140.

23 SAS INSTITUTE. SAS/SAT User's guide - version 6. Cary: NC, 1995. 
G. C. Ferraro et al. EFFECT OF SNAKE VENOM DERIVED FIBRIN GLUE ON THE TENDON HEALING IN DOGS. CLINICAL AND BIOMECHANICAL STUDY. J. Venom. Anim. Toxins incl. Trop. Dis., 2005, 11, 3, p. 273

24 SCHWARZ RL. Modeling tendon morphogenesis in vivo based on cell density signaling in cell culture. J. Math. Biol., 1996, 35, 97-113.

25 SILVA MJ., BOYER MI., GELBERMAN RH. Recent progress in flexor tendon healing. J. Orthop. Sci., 2002, 7, 508-14.

26 THERMANN H., BECK A., HOLCH M., BIEWENER A., BOSCH U., FRERICHS, O. Functional treatment of acute Achilles tendon rupture. A histological, immunohistological and ultrasonographic analysis of the animal model. Unfallchirurg., 1999, 102, 447-57.

27 THERMANN H., FRERICHS O., BIEWENER A., KRETTEK C. Healing of the Achilles tendon: an experimental study. Foot Ankle Int., 2001, 22, 478-83.

28 THERMANN H., FRERICHS O., BIEWENER A., KRETTEK C., SCHANDELMEIER P. Functional treatment of acute rupture of the Achilles tendon. An experimental biomechanical study. Unfallchirurg., 1995, 98, 50713.

29 THERMANN H., FRERICHS O., HOLCH M., BIEWENER A. Healing of the Achilles tendon, an experimental study: part 2--histological, immunohistological and ultrasonographic analysis. Foot Ankle Int., 2002, 23, 606-13.

30 THOMAZINI-SANTOS IA. Adesivo de fibrina derivado de veneno de serpente: efeito da adição do ácido epsilon-aminocapróico, do ácido tronexâmico e da aprotinina na coaptação das bordas cirúrgicas em incisões de pele de ratos. Botucatu: Universidade Estadual Paulista, Faculdade de Medicina, 2000. 132p. [Tese - Doutorado]

31 TSAI WC., TANG FT., HSU CC., HSU YH., PANG JH., SHIUE CC. Ibuprofen inhibition of tendon cell proliferation and up regulation of the cyclin kinase inhibitor p21CIP1. J. Orthop. Res., 2004, 22, 586-91.

32 VOLLMAR D., Kombination fibrinklebung mit chirurgischer naht bei Achillessehnenruptur. In: COTTA H., BRAUN A. Fibrinkleber in orthopadie und traumatologie. Stuttgart: Thieme-Verlag, 1982: 138.

33 WANG ED. Tendon repair. J. Hand Ther., 1998, 11, 105-10. 
G. C. Ferraro et al. EFFECT OF SNAKE VENOM DERIVED FIBRIN GLUE ON THE TENDON HEALING IN DOGS. CLINICAL AND BIOMECHANICAL STUDY. J. Venom. Anim. Toxins incl. Trop. Dis., 2005, 11, 3, p. 274

34 WIIG M., ABRAHAMSSON SO., LUNDBORG G. Tendon repair: cellular activities in rabbit deep flexor tendons and surrounding synovial sheaths and the effects of hyaluronan - an experimental study in vivo and in vitro. J. Hand Surg. Am., 1997, 22, 818-25.

35 YALAMANCHI N., KLEIN MB., PHAM HM., LONGAKER MT., CHANG J. Flexor tendon wound healing in vitro: locate up-regulation of TGF- $\beta$ expression and functional activity. Plast. Reconstr. Surg., 2004, 113, 625-32. 